\title{
Engaged Intermediaries to Bridge the Gap between Scientists, Educational Practitioners and Farmers to Develop Sustainable Agri-Food Innovation Systems: A US Case Study
}

\author{
Aurélie Cardona ${ }^{1, *(\mathbb{D},}$, Cristiana Carusi ${ }^{2}$ and Michael Mayerfeld Bell ${ }^{3}$ \\ 1 INRAE, UR 0767 Ecodéveloppement, 84140 Avignon, France \\ 2 Center for Integrated Agricultural Systems, University of Wisconsin-Madison, Madison, WI 53706, USA; \\ cecarusi@wisc.edu \\ 3 Department of Community and Environmental Sociology, University of Wisconsin-Madison, \\ Madison, WI 53706, USA; michaelbell@wisc.edu \\ * Correspondence: aurelie.cardona@inrae.fr
}

check for

updates

Citation: Cardona, A.; Carusi, C.; Bell, M.M. Engaged Intermediaries to Bridge the Gap between Scientists, Educational Practitioners and Farmers to Develop Sustainable Agri-Food Innovation Systems: A US Case Study. Sustainability 2021, 13, 11886. https:// doi.org/10.3390/su132111886

Academic Editors: Teodor Rusu and Antonino Galati

Received: 15 August 2021

Accepted: 26 October 2021

Published: 27 October 2021

Publisher's Note: MDPI stays neutral with regard to jurisdictional claims in published maps and institutional affiliations.

Copyright: (c) 2021 by the authors. Licensee MDPI, Basel, Switzerland. This article is an open access article distributed under the terms and conditions of the Creative Commons Attribution (CC BY) license (https:// creativecommons.org/licenses/by/ $4.0 /)$.

\begin{abstract}
This article analyses the role of intermediaries' engagements to bridge the gaps between research, education and practice in the processes of knowledge production needed for the shift to sustainable agri-food systems. It is based on an immersive study of an intermediary organization in the USA, including comprehensive interviews with the staff of the organization about their professional activities, their career paths, their close and longstanding professional relationships, and their values. Three characteristics of engaged intermediaries are identified, which can be positive add-ons for bridging activities: they consider farmers and scientists as equal contributors to the production of knowledge; they are involved in multiple life-worlds: for instance, being both a farmer and an outreach specialist or scientist; and they are closely associated with movements furthering the development of local and sustainable agri-food systems and an equitable sharing of knowledge. The article addresses topics often neglected in the innovation systems literature: the experience, social relations and political engagement of intermediary actors.
\end{abstract}

Keywords: transition; knowledge production; sustainable; agriculture; innovation systems

\section{Introduction}

\subsection{Systemic Approaches for Agricultural Change}

As the necessity for developing sustainable farming systems that use fewer synthetic inputs has become increasingly clear in recent decades, public policies and research studies have been implemented to foster environmentally friendly farming practices and innovations for sustainable agriculture. The pace of change remains slow, however, especially in countries with easy access to synthetic inputs. This difficulty of shifting from conventional to more sustainable crop protection practices, including Integrated Pest Management (IPM) and organic practices, has been explained by path dependency theory [1,2]. People and organizations are caught in particular routines, rules and interactions that define the orientation of the socio-technical system and are hard to change. Several studies have applied this theory to the agricultural sector and identified not only technical but also social "lock-in" mechanisms that stifle transformation [3,4]. From this perspective, it appears increasingly clear that going from an industrial to a sustainable model requires the entire agri-food socio-technical system transformation [5,6]. New spaces of dialogue between these stakeholders need to be created in order to solve organizational issues and to facilitate knowledge sharing and learning processes conducive to new forms of agriculture that are less dependent on synthetic inputs. In recent studies, this question of rethinking the interactions of the actors in the agri-food system has been approached primarily in two ways: either by focusing on the emergence of alternative relations and governance mechanisms in agri-food systems [7-9] or by focusing on intermediary actors and organizations 
acting as a broker in any aspect of the innovation process between two or more parties and contributing to the transformation of knowledge management and learning processes in agricultural innovation $[10,11]$. This article takes the latter approach to explore how intermediary people and organizations can renew the relations between research, education and practice in the processes of knowledge production, and then participate actively in the shift to sustainable agri-food systems.

For many years, agricultural science considered that research was done by scientists, then "repackaged" by extension agents, and finally "launched" by farmers [12]. With the development of innovation studies in other fields, agricultural innovation has increasingly come to be understood as a complex process based on learning and on transformed interactions between people, tools and resources $[13,14]$. This is especially true concerning the change towards sustainable agricultural practices-a "wicked problem" that requires knowledge about complex ecological processes and heterogeneous contexts, various farming styles and social configurations, and is often considered to be a "knowledge-intensive change" compared to the process of modernization [15].

The challenge is therefore not only to provide appropriate technology or to develop demand-driven innovation processes, but also and more importantly to explore new organizational principles and institutional arrangements, especially to better bridge the divide between the various actors concerned by agricultural innovation. Many studies have therefore investigated new forms of organization to facilitate interactions between scientists and farmers in order to encourage production and knowledge exchange on sustainable farming systems [16-19]. Even if, overall, agricultural research continues to favour specific technological innovations and often locks out sustainable ones, it appears that the emergence of interdisciplinary and reflexive projects may signal a shift towards more systemic conceptions of innovation processes [20-23].

\subsection{The Role of the Intermediaries}

The recent proliferation of studies on the role of intermediaries in innovation systems may actually be taken as a sign that the interface between research and production is becoming increasingly important, in R\&D as well as in public research [24]. The wide variety of terms used for intermediaries attests to the advancement of this concept and illustrates some of the roles played by intermediaries: "innovation intermediaries", "knowledge or innovation brokers", "systemic intermediaries", "boundary-spanners", "bridgers", "boundary organization", "information intermediaries" and more.

In the agricultural sector the majority of studies view the role of intermediaries through a functionalist lens [25-27], where the intermediary is considered to be "an independent third-party", or a neutral actor with an "impartial position" facilitating interactions between organizations or people where it seems there is no conflict, especially between scientists, policies, business and producers. The intermediary fulfils functions associated with network management: connecting, framing, knowledge brokering and exploring [28].

Concerning the boundaries between science and society, in particular, the intermediary is the bridge linking the interactions between the producers and the users of knowledge. It ensures that demand and supply of research effectively match up. Klerkx and Leeuwis define the intermediary's function as being to clarify both demand and supply, and to establish a dialogue between users and producers of knowledge [29]. This functionalist approach might prove helpful in analysing the processes of renewing interactions between farmers and research. However, from this perspective each actor has a specific function in the innovation system, and scientists are still classically considered to be the main producers of knowledge, while farmers are seen as the end-users of research [30]. Studies that outline the role of intermediaries in technology transfer generally rarely question neither the position of the different actors nor the nature of interactions between them [10]. In the agri-food sector, only a few studies stress the contexts and nature of the relationships between intermediaries and other actors [31-36]. 


\subsection{What about Intermediaries' Engagement?}

Moreover, the innovation systems literature rarely looks favourably on the political engagement of intermediaries, which would "imply that their existence remains limited to the lifecycle of the issues they represent in societal debate" [27]. Of course, the neutrality of intermediaries has already been called into question, especially when they are the source of the innovation and are necessarily more engaged than when they facilitate change [37]. It is also clear that, in order to fulfil their roles, intermediaries always exercise a certain degree of steering, at least through their informal activities and their personal relationships with stakeholders [27]. Intermediaries with strong visions and expectations can be a driver in the transition processes $[38,39]$.

This is especially true in the context of transitions towards more sustainable agri-food systems. These processes are complex and sometimes generate conflict over means and goals. They involve "living materials" that cannot be fully controlled and that can be managed in various ways [40]. They encompass citizens' attitudes towards environmental considerations such as maintaining or restoring water quality for human consumption and aquatic life, avoiding biodiversity erosion, and imply "socio-political choices in which intermediaries can hardly claim their neutrality" [41]. It has been shown that in such contexts, the engagement of intermediaries can serve as a resource to legitimize innovations (e.g., in organic farming) [42] and to envision a future where agriculture supports innovation processes [33,43].

However, studies rarely focus on the origin and nature of intermediary engagement. This article addresses the following questions: how is engagement of intermediary actors built? Where does it come from? How does engagement intersect with intermediary activities? In our study, we focus on a case study of an organization, the Center for Integrated Agricultural Systems (CIAS), which is part of the University of WisconsinMadison College of Agricultural and Life Sciences in the United States. Our objective is to explore the hypothesis that brokering is fostered when intermediary activities are embedded in specific relationships and engagement of intermediary actors. We adopt a pragmatic point of view to explore how intermediaries' life-world engagement in farming and research can legitimize their intermediary activity. Life-world means here the sphere of reality in which they engage, that is, not only the natural but also the social and cultural worlds they experience [44]. We also look at their political engagement in environmental organizations and social movements such as the local food movement.

\section{Materials and Methods}

\subsection{Case Study}

During the 1980s, and as in the case at other US universities, UW was accused by family farmers and environmental organizations of focusing on large-scale, capital-intensive commodity production at the expense of low-input, sustainable farming systems. The Wisconsin Rural Development Center (WRDC), a non-profit organization formed in 1983 by family farmers with help from a former UW agricultural scientist, conducted research and demonstration projects to fill this need for low-input agriculture research [45]. This effort was not however enough to address the serious challenges faced by Wisconsin farmers. Family-owned dairy farms, which are the basis of Wisconsin's agriculture, were especially threatened by the farm crisis. Criticism of the university intensified in 1988, when the ongoing farm crisis was coupled with a severe drought and farmers complain that research did not take in account their interests. Farmers raised their voices to demand closer alignment between their needs and university research. This led to the creation of CIAS in 1989, by a coalition of farmers and farm and environmental organizations, University of Wisconsin (UW) faculty, and other citizens mobilized to build political and financial support for sustainable agriculture research and extension at UW-Madison. During the same period several university centers across the US were also founded, dedicated to sustainable agriculture and committed to improving relations with farmers [46]. 
CIAS was established independently of any department, in the UW-Madison College of Agricultural and Life Sciences (CALS). The original mission of CIAS was: "To foster and support applied interdisciplinary research related to agricultural sustainability, including economic viability and resource protection" (from "A Proposal in Support of a Center for Integrated Agricultural Systems in the College of Agricultural and Life Sciences-UWMadison". Submitted to the Wisconsin Legislature in March 1989) through networking, bridging and educational activities. To do so, since its inception, CIAS has worked closely with a Citizens Advisory Council (CAC) composed primarily of practitioners (farmers, food manufacturers, representatives of farmers' unions or farmers' organizations, etc.) to ensure the " ... active involvement of low-chemical farmers and the interested public in these programs to assure the initiatives will meet actual information needs of Wisconsin farmers" (addendum to "Proposal for Research and Information Delivery on Environmentally Sound Farming Practices". Submitted to the Wisconsin Legislature in 1989).

Now, CIAS is organized as a hub of people working with partners on and beyond the UW-Madison campus. This hub consists primarily of non-faculty staff members working in outreach and communications (around 10 people). They work under the leadership of a faculty director and partner with around 60 faculty associates from CALS and the College of Letters and Science. Additionally, CIAS extends its capacity without expanding its personnel budget, by working with associate staff employed by other campus units and UW-Extension (3 people), and student associates primarily from the F.H. King Students for Sustainable Agriculture student organization. CIAS continues to work closely with a Citizens Advisory Council (CAC) (15 people) that meets biannually with CIAS staff, associate staff and faculty. As an intermediary organization, CIAS can be compared to a multi-stakeholder platform [25] that is radially organized [47], with outreach and communication staff at its centre.

The CIAS activities can be clustered in three distinct yet overlapping categories: communication, training and education, and research. The following table provides examples of current CIAS activities in each of these categories (Table 1):

Table 1. CIAS activities.

\begin{tabular}{|c|c|c|}
\hline Communication & Training and Education & Research \\
\hline $\begin{array}{l}\text { - } \quad \text { Research Briefs: 2-page documents } \\
\text { summarizing research on sustainable } \\
\text { agri-food systems. The first CIAS } \\
\text { Research Brief was published in } 1992 \\
\text { - } \quad \text { Brochures } \\
\text { - } \quad \text { Reports on sustainable and organic } \\
\text { farming and food systems } \\
\text { - } \quad \text { Website and social media } \\
\text { - } \quad \text { Email updates sent to a list of over } \\
\text { 1000 subscribers } \\
\text { - } \quad \text { Presentations and displays at research } \\
\text { and technical conferences } \\
\text { - } \quad \text { Public events } \\
\text { - Research Briefs: 2-page documents } \\
\text { summarizing research on sustainable } \\
\text { agri-food systems. The first CIAS } \\
\text { Research Brief was published in } 1992 \\
\text { - Brochures } \\
\text { - Reports on sustainable and organic } \\
\text { farming and food systems } \\
\text { - Website and social media } \\
\text { - Email updates sent to a list of over } \\
\text { 1000 subscribers }\end{array}$ & 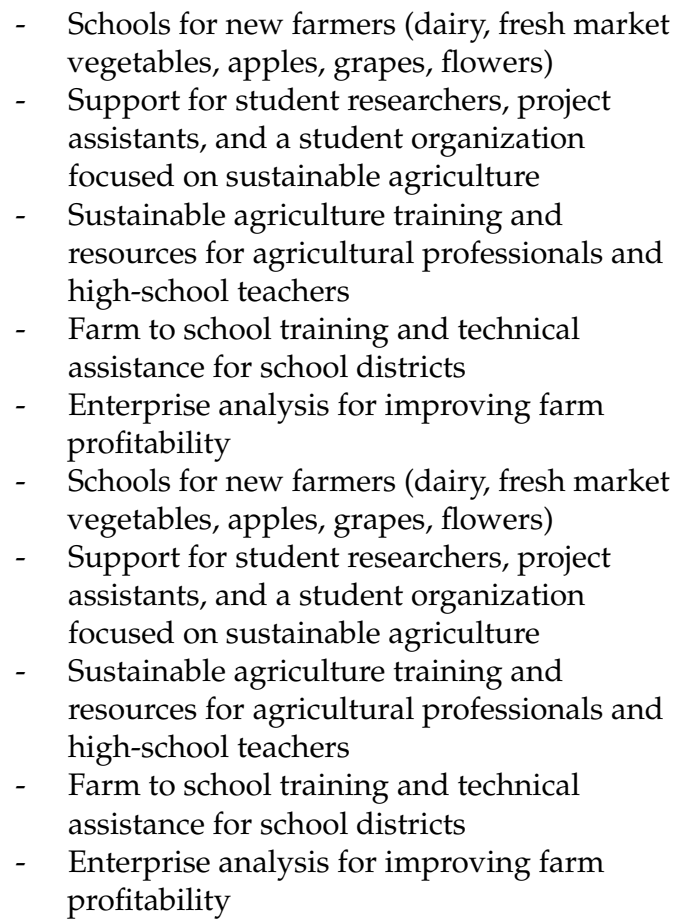 & $\begin{array}{ll}- & \text { Grazing } \\
\text { - } & \text { Local and regional food } \\
& \text { systems } \\
\text { - } & \text { IPM } \\
\text { - } & \text { Organic farming } \\
\text { - } & \text { Labour } \\
- & \text { Perennial agriculture and } \\
& \text { agro-forestry } \\
- & \text { Climate change } \\
- & \text { Food systems transportation } \\
- & \text { Grazing } \\
- & \text { Local and regional food } \\
\text { - } & \text { systems } \\
- & \text { Organic farming } \\
- & \text { Labour } \\
- & \text { Perennial agriculture and } \\
& \text { agro-forestry } \\
- & \text { Climate change } \\
- & \text { Food systems transportation }\end{array}$ \\
\hline
\end{tabular}


Based on its original mission statement, organization and current activities, CIAS fulfils the function of an intermediary organization. As presented in the Introduction section, our study wants to show how intermediary function also relies on some characteristics and relationships of the people working in the organization.

\subsection{Methods}

This study was based on an abductive approach aiming at producing new hypotheses and theories based on surprising research evidence [48]. A French scientist (the first author of this article), familiar with the European literature about intermediaries in system innovation, made a six-month immersion, from March to September 2014, in an American intermediary organization as a participant observer. In focusing on a specific organization, its staff and its bounded context, we developed a case study research [49]. Close relationships were established with two members of the organization, considered as informants, and who eventually participated in writing this article (second and third author of this article). With this methodology, we assumed a constructivist position that emphasized the subjective interrelationship between scientist and participants, and the co-construction of meaning [50].

We use several methods in order to produce different kinds of evidence, which crossvalidated our provisional hypothesis formulated according to an inductive process [51]. This approach is in line with the recommendations of Yin [52], according to which, case study research should rely on multiple sources of evidence.

The immersion included participant observation of specific events (strategic meetings about the organization's future and its 25th anniversary, and meeting with its Citizen Advisory Council) and of the organization's weekly staff meetings where past, current and future activities were discussed. More specifically, conversations about grant applications, the budget and links with other institutions such as the university and farmer associations increased understanding of the intermediary organization. Participant observation was useful both to get to know the people working in such an organization, and to observe their day-to-day work. It increased understanding of both the social configurations within which the actors worked, and their connections, including how these connections could serve as resources or constraints. Informal conversations with the participants also helped to reveal their interpretations of the observed situations. This participant observation produced detailed descriptions of the interactions between people, of their preoccupations and of their actions. It helped to identify provisional hypotheses about the nature of their relationships and its impact on their intermediary activities. The immersion also included comprehensive interviews (10) with the staff of the organization, oriented by the first analysis stemming from the participant observation. The interviews focused on their professional activities, their career paths, their close professional relationships, and their ideas about promoting their organization's mission. The interviews were analysed:

- To list the various activities of each interviewee at the time of the interview;

- $\quad$ To map the professional trajectories of the interviewees and see how former activities or professional relationships impacted their current intermediary activity;

- $\quad$ To determine the relationships between the different actors both within the organization and outside of the organization;

- $\quad$ To understand how these relationships were characterized by the interviewees.

In order to present the in-progress analyses of the "immersed scientist" to the studied intermediary actors, and to encourage formal discussions, two workshops with the interviewees were held. They facilitated a continuous interplay between analysis and data collection and were an opportunity to validate the analysis with the actors themselves [53]. The research furthermore included a review of archive documents describing the history of the intermediary organization. The aim was to understand how and in what context it had emerged, who its supporters and sceptics were, and how its place in the institutional landscape had evolved over time. It was thus an exploration of the organization's local social anchorage. 


\section{Results}

\subsection{Considering Farmers and Scientists as Equal Contributors in the Production of Knowledge}

Close examination of the relationship established between the people carrying out these activities shows that the intermediation process stems not only from the nature of the activities carried out by CIAS, but also from the fact that CIAS staff, associate staff, UW faculty associates, student associates and CAC members (farmers, food manufacturers, etc.) are considered as equal contributors in the production of knowledge [54].

As regards communication, CIAS Research Briefs summarize academic work, commonly authored by CIAS faculty associates and their students. These Research Briefs are reviewed by at least one farmer, one extension agent and one faculty member. The process helps to translate academic knowledge in a language and a format accessible to a practitioner audience. It can also sometimes lead to a production of new knowledge adapted to practitioners needs. For instance, several years ago this review process led to a new interpretation of a study on grazing:

The review process is a very give-and-take kind of thing. I'm thinking of a Research Brief we did [ ... ]. There wasn't a real strong conclusion to the research .... And when I sent it to the faculty person and the extension agent, they were ok with it. But the farmer looked at it and came up with some different conclusions, they were stronger conclusions, and they were things we could actually say, and so we ended up changing what the brief said because the farmer was like: Oh did you notice on your graph, how much taller the line was for orchard grass or meadow fescue? (Communication specialist, CIAS)

The story of this small event reveals the specific posture of CIAS: farmers, extension agents and faculties are considered as equal knowledge producers. This posture is a key element ensuring that communication is a two-way process bridging differences in knowledge systems and allowing potential end-users to question and transform academic work $[55,56]$. Therefore, communication is not only considered as an intermediary function between science and practice, but also as an activity fulfilling a role of network and knowledge brokerage, facilitation, exchange and learning. Communication thus contributes to "re-ordering the social relationships" in the agri-food system and to providing a space for creative interaction around innovation [57]. Of course, it implies skilled communicators who consider communication as an interactive process; that is to say, there are reciprocal influences between the different participants to the process. More specifically, it implies a form of interpersonal communication in which feedback in communication processes is valued, and the contribution of the "person-situation context" and the people involved in the communication process (especially their knowledge) are taken seriously [58].

As regards educational activities, all CIAS schools for new farmers draw on the expertise of both faculty members and farmers as instructors. First, because CIAS staff members heading its farm schools are also farmers. Second, because they invite other farmers to teach in the schools, convinced that "the growers are the best instructors!" (Outreach specialist, CIAS). These farmers are drawn from the CAC or other networks in which CIAS staff members are involved. This grower-instructor approach to farmer training represents a reversal of traditional roles in the diffusion of innovations.

CIAS research activities are also driven by the desire and commitment to involve both farmers and scientists as equal contributors to develop practices and innovations that respond to the needs of farmers or, more generally, the public. Most CIAS research programmes emerge from ideas discussed at the biannual CAC meetings. CIAS' research approach can therefore be described as "taking ideas that farmers have and finding resources to figure out and make it happen" (Outreach specialist, CIAS). Large parts of these research programmes are therefore conducted according to the principles of participatory research involving focus groups and farms as field experiment sites. Other programmes can be considered as action research insofar as they aim to help farmers or food processors to define research: 
What my part of research work is: what is the scene, who has a stake in the game, who are the leaders? Then, I try to bring them to speak together-what are their needs? - to bring the people around the table. [... I And to me, that's research. And it's not research like in university; it's about farmers defining the research topic. (Outreach specialist, CIAS)

Once a research topic has been defined, the role of CIAS is to connect interested farmers with faculty members working in relevant fields, and to help them to work together in a research programme. An example among several research programmes on grazing, food transportation and so on, initiated in this way, was the research programme for the development of IPM in apple orchards. It started at the end of the 1990s, after a CIAS outreach specialist talked about a previous study on pesticide reduction with potato growers at an apple growers meeting. It appeared that some of the apple growers were interested in pesticide reduction, in a context where the Environmental Protection Agency (EPA) planned to remove some pesticides.

We rounded up scientists on campus and some small groups of motivated growers. We did multiple meetings for about two years. We sat around and thought about if we were going to do pesticide reduction in apples what would that look like? What were the most toxic pesticides? What were the highest risk pesticides? [ . . ] So we were learning all about this and sharing information across the board. [ ... ] And then, we developed a system where farmers could keep track of their pesticide use and figure out if they were reducing pesticide risk at all. And one of the things we wanted to do also was to show if farmers used IPM that it would then reduce risk because there was no way of proving that before, we had no hard numbers for that. When we started to mess about with that issue, EPA became very interested and started funding us to do this work. So in 2002 we got our first grant to start doing field work in 2003 with apple growers, and we were able to get money to give growers some in-field assistance ... in access to tools. (Outreach specialist, CIAS)

CIAS research programmes are thus built not only on the "farmer first" principle of the 1980s, but also want to hybridize scientific and stakeholder knowledge [59]. Even if this CAC was a structure that had been cited as a model for rethinking the relationships between agricultural science and farmers $[17,60,61]$, it is not a guarantee for eliminating scientists' domination of farmers. The director of the CIAS explains that even if the staff asks the CAC what their current preoccupations are, in order to determine the research programme, the staff of the CIAS is not forced to work on what they suggest. He describes the process of choice of research topics as a "loose process, different each year" without written rules. CIAS staff members and faculties decide whether or not their knowledge of methodological approaches can contribute to further problem solving on the suggested topics, as is usually done even in user-oriented research [16]. However, if the CAC's suggestions are not taken into account by the CIAS staff, it has to justify itself, and in case of discontent the CAC can complain to the dean of the university, who can take measures against the CIAS. Yet these methods do nonetheless afford an opportunity to rethink the relationships between the actors in agricultural innovation and knowledge systems.

\subsection{Life-Worlds and Political Engagement as a Source of Legitimacy for Intermediaries}

While scholars usually advocate for the neutrality of intermediary organizations, the intermediary activities developed by CIAS rely on strong life-world and political engagements. CIAS is organized as a hub of people with different positions. Yet, looking more closely at the people level, we see that it is not only a question of positions, for the people working for the CIAS are also involved in different "life-worlds" with their own rules, objectives and constraints undergirding their actions. Several members of the CIAS staff mentioned they were comfortable having at least "two or three interchangeable hats" (Outreach specialist, CIAS). In addition to working at CIAS, some of these staff members are actively farming. For instance, the outreach specialist who leads CIAS's Wisconsin School for Beginning Market Growers grows and sells fresh market vegetables. 
Likewise, the two CIAS staff leaders of the Wisconsin School for Beginning Dairy and Livestock Farmers breed grass-fed cattle for beef. In that sense, those people belong to several "communities of practice", and know which norms, interests and purpose [62] can help them in their intermediary activities. Several CIAS outreach specialists explained for example how their own farming experience helped them to engage in discourse intended to meet farmers' needs:

My partner is farming, so I feel like I'm able to connect well with that because we're dealing with the same stuff that these beginning farmers are dealing with. Whether they have to get a license to sell in the farmers market or... I think it's good that I have that sort of on-the-ground perspective, because when students come to me and say, 'How do I do this?', I know 'this' is really hard. (Outreach specialist, CIAS)

Having multiple affiliations strengthens the ability to take into account several points of view at the same time. Several members of the CIAS staff thus share an in-depth experience of the different life-worlds they aim to link up. It helps them to establish trustworthy relationships with the people from those life-worlds. Belonging to different life-worlds is however not the only form of engagement of this intermediary actors. Many CIAS staff members were also engaged in teaching or communication activities before their CIAS employment, often with grassroots sustainable agriculture organizations. This experience, along with staff members' immersion in multiple life-worlds, enhances CIAS to reach its bridging objectives.

Most of them are also politically engaged in the development of a more sustainable agriculture and a more integrated knowledge system. Most CIAS staff members are or have been involved with movements promoting environment-friendly approaches of food production such as the F.H. King Student Farm which fosters "the relationship between land, food, and the UW-Madison campus community as well as the surrounding Madison community through garden workshops and shared learning experiences", the Community Supported Agriculture (CSA) movement, or the Wisconsin graziers' organization. Moreover, CIAS staff members regularly mention the "Wisconsin Idea" as an anchorage for CIAS' mission in Wisconsin history. The "Wisconsin Idea", which is still a very vivid concept in this State, was created by Robert M. La Follette, cornerstone of the US Progessive politival movement and Wisconsin's governor from 1901 to 1906 and US senator from 1906 to 1925, calling for a government serving the people and based on the involvement of specialists in law, economics, and social and natural sciences, to avoid control of institutions by special interest groups.

The political engagement of CIAS staff concerns both the future of the agri-food system and agricultural science and provides them a resource for achieving common visions. It reinforces CIAS' purpose and legitimacy, which are anchored in a specific system of values that CIAS members share with others outside the organization. These political engagements and the resulting relationships lend legitimacy to CIAS as an intermediary organization can also led to conflictual situation. In 2010, the dean of the College of Agriculture and Life Science (CALS) called into question the mission and organization of CIAS, mainly because of personal difficulties with the director [46]. Some members of the CIAS staff alerted their networks to this situation. As is often the case in conflictual situations, the threat led to greater cohesion and reinforcement of the group [63,64]. Many local movements and personalities reacted in support of CIAS. Facing strong negative reactions from the public, CALS rapidly withdrew its challenge. Whereas nationally some sustainable agricultural research centres have disappeared as a result of budget cuts, CIAS survived the crisis of 2010 because strong citizen support helped it navigate through conflict.

\section{Discussion}

\subsection{The Challenge of Shared Power}

Our results show that CIAS aims to balance the traditional power relationships between scientists and farmers as much in its communication and educationnal activities as in in its research programmes, for example in favouring participatory action research 
in order to produce more integrative agricultural science [65], but also in establishing a specific governance system including a CAC. However, there is no guarantee that scientists and farmers will manage to work together as colleagues [23] or "equal partners" [30]. The question of ambiguity of power in the governance process can surface at any moment, even in the more virtuous participatory collaboration between scientists and farmers [66]. For example, in our case study, scientists are the one who are the decision makers concerning the choice of research topics. Even if the CAC can refer to the dean in case of discontent, we can imagine it would be counterproductive if it undermines relationships between CAC members and CIAS. As already shown in other studies (e.g., [67]), partnerships with scientists can provide resources to stakeholders: financial resources through research project or workforce of students involved in research projects paid by the university. In these conditions, would it be then really possible that CAC members refer to the dean? A limitation of our study is that we only considered CIAS staff members. In order to better understand what are the challenges of shared power in this organization, it would have been interesting to conduct supplementary interviews to analyse how CAC members considers their relationships with CIAS staff members, associate staff, faculty members and students.

\subsection{The Challenge of Trustworthy Relationships}

Our results also show how having intermediary actors with engagement in different life-worlds is an interesting mean to reinforce collaborative work between scientists, outreach specialists, extension agents and farmers. We know that sustainable farmers sometimes have trouble trusting extension services [68] or environmental government agencies [69] or simply consider it risky to adopt innovations coming from "socially distant outsiders" [16]. Shared values are a key element of the collaboration processes, between scientists [70] but also between scientists and farmers [66]. With the recognition of transdisciplinarity understood as problem-solving strategies based on close interactions between scientists and other actors and considered as a relevant approach to develop sustainable farming [71-74], the engagement in different life-world can constitute a "passport of legitimacy" $[75,76]$ in the eyes of both faculties and farmers. The trustworthy relationships established in the different life-worlds can foster knowledge production processes involving diverse stakeholders in the agri-food system. Yet, doing research while wearing multiple hats is not always viewed favourably by faculty members, as some CIAS staff members have reported. Most scientists still often consider themselves as objective and rational 'experts', and as such they can be "hesitant to relinquish power and control to embrace knowledge from 'non-experts'" [66]. This points out the importance of long-term and trustworthy relationships not only between intermediary actors and farmers, but also between intermediary actors and scientists. Then, as a further development of this idea, it could be interesting to analyse if and how the increase in the number of staff positions relying on "soft money" and short-term grants leading to high staff turnover impacts the anchorage of the organization in different life-worlds-including university life-world-and possibly resulting in a weakening of its intermediation power.

\subsection{The Challenge of Engagement}

Our results show how intermediary actors, usually considered as a neutral third-party, can benefit from their life-worlds and political engagement. A limitation concerning this result is that it comes from an abductive approach relying on attention to surprising empirical findings against a background of existing theories [48], i.e., literature on intermediary actors in systems of innovation. For further development of this research, it could be interesting to discuss our results in the light of the literature on stakeholder engagement in the management and business field. This literature focus on the role of individuals in transition processes, front-runners and stakeholders standing up for transition processes who can incidentally assume a role of intermediary actors $[77,78]$. 
Concerning operational implications of this result, we can consider that engagement could also have negative impacts on intermediary activities. We know that shared values facilitate cooperation between actors [66]. On the opposite, if the engagement for specific values is not shared, it can lead to exclusion. In our case study, intermediary actors are engaged in the development of a more sustainable agriculture and a more integrated knowledge system. These engagements ensure them support from movements and organizations involved in environment-friendly approaches of food production. We can imagine that it excludes some conventional actors or organizations and then reduce the capacity of intermediary actors to foster transition processes. Future research could be carried out to explore these phenomenons of exclusion and their impact on transition processes at the State level.

\section{Conclusions}

Sustainable and environmentally friendly agri-food systems are emerging and thriving around the world. However, the shift to these kinds of systems remains slow, which raises questions about our understanding of transition processes. In recent decades, we have progressively moved from linear models of diffusion of innovation towards more integrative, system approaches. Many studies have looked at the role of intermediaries and intermediation processes to better link the different actors and components of agri-food systems for transition processes and development of innovations. While there are many arguments supporting impartiality in intermediary processes, this study questions the emphasis on neutral intermediaries in the transition to sustainable agri-food systems, and shows how the engagement of intermediary actors is a resource fostering sustainable practices and systems. The study of CIAS, an organization aimed at developing sustainable agricultural research, training and education, and communication, while fostering stronger relations between the university and farmers, provides an example of what can be the engagement of intermediary actors and how it can legitimize their activities. Here, engagement has been defined in three ways: (i) consideration of farmers and scientists as equal contributors in communication, education and research activities; (ii) involvement in multiple life-worlds: for instance, being both a farmer and an outreach specialist, or an outreach specialist and, at the same time, a student or scientist; (iii) association with movements - or at least sharing values with movements-furthering the development of local and sustainable agri-food systems and an equitable sharing of knowledge.

The findings of this study about the engagements of the intermediary actors directly contribute to understanding how we can encourage balanced and trustworthy relationships between the actors of the agri-food system of innovation which can favour exchange of knowledge.

We hope this article will open dialogue on the experiences and values of intermediary actors, and thus further our understanding of the role they play in the successes-or the failures-of changes to sustainable agri-food systems.

Author Contributions: Conceptualization, A.C. and M.M.B.; methodology, A.C.; validation, M.M.B. and C.C.; formal analysis, A.C.; investigation, A.C.; data curation, A.C.; writing-original draft preparation, A.C.; writing-review and editing, C.C.; supervision, M.M.B.; funding acquisition, A.C. All authors have read and agreed to the published version of the manuscript.

Funding: This research was funded by INRAE, department ACT, SADIB2014.

Institutional Review Board Statement: The study was conducted according to the guidelines of the Declaration of Helsinki, and approved by the Educational and Social/Behavioral Institutional Review Board of the University of Wisconsin-Madison (ED/SBS IRB\#: 2014-0800. Date of approval: 28 July 2014).

Informed Consent Statement: Informed consent was obtained from all subjects involved in the study.

Data Availability Statement: The data presented in this study are available on request from the corresponding author. 
Acknowledgments: The first author acknowledges CIAS for its warm welcome during the six months' immersion, and especially CIAS staff members who participated to the study.

Conflicts of Interest: The authors declare no conflict of interest.

\section{References}

1. Arthur, W.B. Competing Technologies, Increasing Returns, and Lock-in by Historical Events. Econ. J. 1989, 99, 116-131. [CrossRef]

2. Dosi, G. Technological Paradigms and Technological Trajectories: A Suggested Interpretation of the Determinants and Directions of Technical Change. Res. Policy 1982, 11, 147-162. [CrossRef]

3. Sutherland, L.-A.; Burton, R.J.F.; Ingram, J.; Blackstock, K.; Slee, B.; Gotts, N. Triggering Change: Towards a Conceptualisation of Major Change Processes in Farm Decision-Making. J. Environ. Manag. 2012, 104, 142-151. [CrossRef]

4. Vanloqueren, G.; Baret, P.V. Why Are Ecological, Low-Input, Multi-Resistant Wheat Cultivars Slow to Develop Commercially? A Belgian Agricultural Lock-in'case Study. Ecol. Econ. 2008, 66, 436-446. [CrossRef]

5. Lowe, P. Industrial Agriculture and Environmental Regulation: A New Agenda for Rural Sociology. Sociol. Rural. 1992, 32, 4-10. [CrossRef]

6. Gliessman, S.R. Agroecology: The Ecology of Sustainable Food Systems; CRC Taylor and Francis Group: Santa Cruz, CA, USA, 2007; ISBN 0-8493-2845-4.

7. Lamine, C.; Renting, H.; Rossi, A.; Wiskerke, J.S.C.; Brunori, G. Agri-Food systems and territorial development: Innovations, new dynamics and changing governance mechanisms. In Farming Systems Research into the 21st Century: The New Dynamic; Darnhofer, I., Gibbon, D., Dedieu, B., Eds.; Springer: Dordrecht, The Netherlands, 2012; pp. 229-256.

8. Renting, H.; Van Der Ploeg, J.D. Reconnecting Nature, Farming and Society: Environmental Cooperatives in The Netherlands as Institutional Arrangements for Creating Coherence. J. Environ. Policy Plan. 2001, 3, 85-101. [CrossRef]

9. Sonnino, R.; Marsden, T. Beyond the Divide: Rethinking Relationships between Alternative and Conventional Food Networks in Europe. J. Econ. Geogr. 2006, 6, 181-199. [CrossRef]

10. Howells, J. Intermediation and the Role of Intermediaries in Innovation. Res. Policy. 2006, 35, 715-728. [CrossRef]

11. Klerkx, L.; Leeuwis, C. Balancing Multiple Interests: Embedding Innovation Intermediation in the Agricultural Knowledge Infrastructure. Technovation 2008, 28, 364-378. [CrossRef]

12. Carr, A.; Wilkinson, R. Beyond Participation: Boundary Organizations as a New Space for Farmers and Scientists to Interact. Soc. Nat. Resour. 2005, 18, 255-265. [CrossRef]

13. Röling, N.G. The Emergence of Knowledge Systems Thinking: A Changing Perception of Relationships among Innovation, Knowledge Process and Configuration. Knowl. Policy 1992, 5, 42-64. [CrossRef]

14. Knickel, K.; Brunori, G.; Rand, S.; Proost, J. Towards a Better Conceptual Framework for Innovation Processes in Agriculture and Rural Development: From Linear Models to Systemic Approaches. In Proceedings of the Empowerment of the Rural Actors: A Renewal of Farming Systems Perspectives: 8th European IFSA Symposium, Clermont-Ferrand, France, 6-10 July 2008; pp. 883-893.

15. Winter, M. New Policies and New Skills: Agricultural Change and Technology Transfer. Sociol. Rural. 1997, 37, 363-381. [CrossRef]

16. Hoffmann, V.; Probst, K.; Christinck, A. Farmers and Researchers: How Can Collaborative Advantages Be Created in Participatory Research and Technology Development? Agric. Hum. Values 2007, 24, 355-368. [CrossRef]

17. Lacy, W.B. Research, Extension, and User Partnerships: Models for Collaboration and Strategies for Change. Agric. Hum. Values 1996, 13, 33-41. [CrossRef]

18. Lyon, A.; Bell, M.M.; Gratton, C.; Jackson, R. Farming without a Recipe: Wisconsin Graziers and New Directions for Agricultural Science. J. Rural Stud. 2011, 27, 384-393. [CrossRef]

19. Röling, N.G.; Jiggins, J. Policy Paradigm for Sustainable Farming. Eur. J. Agric. Educ. Ext. 1994, 1, 23-43. [CrossRef]

20. Eshuis, J.; Stuiver, M. Learning in Context through Conflict and Alignment: Farmers and Scientists in Search of Sustainable Agriculture. Agric. Hum. Values 2005, 22, 137-148. [CrossRef]

21. Friedland, W.H.; Ransom, E.; Wolf, S.A. Agrifood Alternatives and Reflexivity in Academic Practice. Rural Sociol. 2010, 75, 532-537. [CrossRef]

22. Van Mierlo, B.; Arkesteijn, M.; Leeuwis, C. Enhancing the Reflexivity of System Innovation Projects with System Analyses. Am. J. Eval. 2010, 31, 143-161. [CrossRef]

23. Lyon, A.; Bell, M.M.; Croll, N.S.; Jackson, R.; Gratton, C. Maculate Conceptions: Power, Process, and Creativity in Participatory Research. Rural Sociol. 2010, 75, 538-559. [CrossRef]

24. Van Lente, H.; Hekkert, M.; Smits, R.; van Waveren, B. Roles of Systemic Intermediaries in Transition Processes. Int. J. Innov. Manag. 2003, 7, 247-279. [CrossRef]

25. Kilelu, C.W.; Klerkx, L.; Leeuwis, C. Unravelling the Role of Innovation Platforms in Supporting Co-Evolution of Innovation: Contributions and Tensions in a Smallholder Dairy Development Programme. Agric. Syst. 2013, 118, 65-77. [CrossRef]

26. Yang, H.; Klerkx, L.; Leeuwis, C. Functions and Limitations of Farmer Cooperatives as Innovation Intermediaries: Findings from China. Agric. Syst. 2014, 127, 115-125. [CrossRef]

27. Klerkx, L.; Leeuwis, C. Establishment and Embedding of Innovation Brokers at Different Innovation System Levels: Insights from the Dutch Agricultural Sector. Technol. Forecast. Soc. Chang. 2009, 76, 849-860. [CrossRef] 
28. Berthet, E.T.; Hickey, G.M. Organizing Collective Innovation in Support of Sustainable Agro-Ecosystems: The Role of Network Management. Agric. Syst. 2018, 165, 44-54. [CrossRef]

29. Klerkx, L.; Leeuwis, C. Matching Demand and Supply in the Agricultural Knowledge Infrastructure: Experiences with Innovation Intermediaries. Food Policy 2008, 33, 260-276. [CrossRef]

30. Klerkx, L.; Leeuwis, C. Operationalizing Demand-Driven Agricultural Research: Institutional Influences in a Public and Private System of Research Planning in The Netherlands. J. Agric. Educ. Ext. 2009, 15, 161-175. [CrossRef]

31. Eastwood, C.R.; Chapman, D.F.; Paine, M.S. Networks of Practice for Co-Construction of Agricultural Decision Support Systems: Case Studies of Precision Dairy Farms in Australia. Agric. Syst. 2012, 108, 10-18. [CrossRef]

32. Elzen, B.; Barbier, M.; Cerf, M.; Grin, J. Stimulating transitions towards sustainable farming systems. In Farming Systems Research into the 21st Century: The New Dynamic; Springer: Dordrecht, The Netherlands, 2012; pp. 431-455, ISBN 94-007-4502-8.

33. Klerkx, L.; Aarts, N.; Leeuwis, C. Adaptive Management in Agricultural Innovation Systems: The Interactions between Innovation Networks and Their Environment. Agric. Syst. 2010, 103, 390-400. [CrossRef]

34. Tisenkopfs, T.; Kunda, I.; šūmane, S.; Brunori, G.; Klerkx, L.; Moschitz, H. Learning and Innovation in Agriculture and Rural Development: The Use of the Concepts of Boundary Work and Boundary Objects. J. Agric. Educ. Ext. 2015, 21, 13-33. [CrossRef]

35. Van Lente, H.; Boon, W.P.C.; Klerkx, L. Positioning of Systemic Intermediaries in Sustainability Transitions: Between Storylines and Speech Acts. Environ. Innov. Soc. Transit. 2020, 36, 485-497. [CrossRef]

36. Blix Germundsson, L.; Augustinsson, S.; Lidén, A. Collaboration in the Making-Towards a Practice-Based Approach to University Innovation Intermediary Organisations. Sustainability 2020, 12, 5142. [CrossRef]

37. Den Hertog, P. Knowledge-Intensive Business Services as Co-Producers of Innovation. Int. J. Innov. Manag. 2000, 4, 491-528. [CrossRef]

38. Kivimaa, P. Government-Affiliated Intermediary Organisations as Actors in System-Level Transitions. Res. Policy 2014, 43, 1370-1380. [CrossRef]

39. Kivimaa, P.; Boon, W.; Hyysalo, S.; Klerkx, L. Towards a Typology of Intermediaries in Sustainability Transitions: A Systematic Review and a Research Agenda. Res. Policy 2019, 48, 1062-1075. [CrossRef]

40. Leeuwis, C. Communication for Rural Innovation: Rethinking Agricultural Extension; Wiley-Blackwell: Hoboken, NJ, USA, 2004; ISBN 1-4051-7647-4.

41. Steyaert, P.; Barbier, M.; Cerf, M.; Levain, A.; Loconto, A.M. Role of intermediation in the management of complex sociotechnical transitions. In AgroEcological Transitions: Changes and Breakthroughs in the Making; Wageningen University \& Research: Wageningen, The Netherlands, 2017; p. 39.

42. Goldberger, J.R. Non-Governmental Organizations, Strategic Bridge Building, and the "Scientization" of Organic Agriculture in Kenya. Agric. Hum. Values 2008, 25, 271-289. [CrossRef]

43. Berkhout, F. Normative Expectations in Systems Innovation. Technol. Anal. Strateg. Manag. 2006, 18, 299-311. [CrossRef]

44. Schutz, A.; Luckmann, T. The Structures of the Life-World; Northwestern University Press: Evanston, IL, USA, 1973; Volume 1, ISBN 0-8101-0622-1.

45. Gordon, M.A. Oral Documentation and the Sustainable Agriculture Movement in Wisconsin. Public Hist. 1989, 11, 83-98. [CrossRef]

46. Haynor, L. Twenty Years Later: Lessons from Three Sustainable Agriculture Center Pioneers at Land Grant Universities. Master's Thesis, University of Wisconsin-Madison, Madison, WI, USA, 2010.

47. Stevenson, S.G.W.; Posner, J.; Hall, J.; Cunningham, L.; Harrison, J. Addressing the Challenges of Sustainable Agriculture Research and Extension at Land-grant Universities: Radially Organized Teams at Wisconsin. Am. J. Altern. Agric. 1994, 9, 76-83. [CrossRef]

48. Timmermans, S.; Tavory, I. Theory Construction in Qualitative Research: From Grounded Theory to Abductive Analysis. Sociol. Theory 2012, 30, 167-186. [CrossRef]

49. Merriam, S.B. Qualitative Research and Case Study Applications in Education. Revised and Expanded from "Case Study Research in Education"; Jossey-Bass Publishers: San Francisco, CA, USA, 1998.

50. Mills, J.; Bonner, A.; Francis, K. The Development of Constructivist Grounded Theory. Int. J. Qual. Methods 2006, 5, 25-35. [CrossRef]

51. Becker, H.S. Problems of Inference and Proof in Participant Observation. Am. Sociol. Rev. 1958, 23, 652-660. [CrossRef]

52. Yin, R.K. Case Study Research Design and Methods, 5th ed.; SAGE: Thousand Oaks, CA, USA, 2014.

53. Emerson, R.M. Observational Field Work. Annu. Rev. Sociol. 1981, 7, 351-378. [CrossRef]

54. Šūmane, S.; Kunda, I.; Knickel, K.; Strauss, A.; Tisenkopfs, T.; Rios, I.d.I.; Rivera, M.; Chebach, T.; Ashkenazy, A. Local and Farmers' Knowledge Matters! How Integrating Informal and Formal Knowledge Enhances Sustainable and Resilient Agriculture. J. Rural Stud. 2018, 59, 232-241. [CrossRef]

55. Ingram, J.; Dwyer, J.; Gaskell, P.; Mills, J.; Wolf, P. de Reconceptualising Translation in Agricultural Innovation: A Co-Translation Approach to Bring Research Knowledge and Practice Closer Together. Land Use Policy 2018, 70, 38-51. [CrossRef]

56. Valdivia, C.; Danda, M.K.; Sheikh, D.; James, H.S.; Gathaara, V.; Mbure, G.; Murithi, F.; Folk, W. Using Translational Research to Enhance Farmers' Voice: A Case Study of the Potential Introduction of GM Cassava in Kenya's Coast. Agric. Hum. Values 2014, 31, 673-681. [CrossRef]

57. Leeuwis, C.; Aarts, N. Rethinking Communication in Innovation Processes: Creating Space for Change in Complex Systems. J. Agric. Educ. Ext. 2011, 17, 21-36. [CrossRef]

58. Hargie, O. Skilled Interpersonal Communication: Theory, Research, and Practice; Routledge: London, UK, 2011. 
59. Berthet, E.T.; Barnaud, C.; Girard, N.; Labatut, J.; Martin, G. How to Foster Agroecological Innovations? A Comparison of Participatory Design Methods. J. Environ. Plan. Manag. 2016, 59, 280-301. [CrossRef]

60. Middendorf, G.; Busch, L. Inquiry for the Public Good: Democratic Participation in Agricultural Research. Agric. Hum. Values 1997, 14, 45-57. [CrossRef]

61. Stevenson, S.G.W.; Klemme, R.M. Advisory/Oversight Councils: An Alternative Approach to Farmer/Citizen Participation in Agenda Setting at Land-grant Universities. Am. J. Altern. Agric. 1992, 7, 111-117. [CrossRef]

62. Morgan, S.L. Social Learning among Organic Farmers and the Application of the Communities of Practice Framework. J. Agric. Educ. Ext. 2011, 17, 99-112. [CrossRef]

63. Coser, L.A. Social Conflict and the Theory of Social Change. Br. J. Sociol. 1957, 8, 197-207. [CrossRef]

64. Simmel, G. The Sociology of Conflict. I. Am. J. Sociol. 1904, 9, 490-525. [CrossRef]

65. Neef, A.; Neubert, D. Stakeholder Participation in Agricultural Research Projects: A Conceptual Framework for Reflection and Decision-Making. Agric. Hum. Values 2011, 28, 179-194. [CrossRef]

66. Barbercheck, M.; Kiernan, N.E.; Hulting, A.G.; Duiker, S.; Hyde, J.; Karsten, H.; Sanchez, E. Meeting the 'Multi-' Requirements in Organic Agriculture Research: Successes, Challenges and Recommendations for Multifunctional, Multidisciplinary, Participatory Projects. Renew. Agric. Food Syst. 2012, 27, 93-106. [CrossRef]

67. Nicklay, J.A.; Cadieux, K.V.; Rogers, M.A.; Jelinski, N.A.; LaBine, K.; Small, G.E. Facilitating Spaces of Urban Agroecology: A Learning Framework for Community-University Partnerships. Front. Sustain. Food Syst. 2020, 4, 143. [CrossRef]

68. Agunga, R.; Igodan, C. Organic Farmers' Need for and Attitude Towards Extension. J. Ext. 2007, 45, 6.

69. Sutherland, L.-A.; Mills, J.; Ingram, J.; Burton, R.J.F.; Dwyer, J.; Blackstock, K. Considering the Source: Commercialisation and Trust in Agri-Environmental Information and Advisory Services in England. J. Environ. Manag. 2013, 118, 96-105. [CrossRef] [PubMed]

70. Tollefsen, D.P. Group Deliberation, Social Cohesion, and Scientific Teamwork: Is There Room for Dissent? Episteme 2006, 3, 37-51. [CrossRef]

71. Aeberhard, A.; Rist, S. Transdisciplinary Co-Production of Knowledge in the Development of Organic Agriculture in Switzerland. Ecol. Econ. 2009, 68, 1171-1181. [CrossRef]

72. Francis, C.A.; Lieblein, G.; Breland, T.A.; Salomonsson, L.; Geber, U.; Sriskandarajah, N.; Langer, V. Transdisciplinary Research for a Sustainable Agriculture and Food Sector. Agron. J. 2008, 100, 771-776. [CrossRef]

73. Hirsch Hadorn, G.; Bradley, D.; Pohl, C.; Rist, S.; Wiesmann, U. Implications of Transdisciplinarity for Sustainability Research. Ecol. Econ. 2006, 60, 119-128. [CrossRef]

74. Méndez, V.E.; Bacon, C.M.; Cohen, R. Agroecology as a Transdisciplinary, Participatory, and Action-Oriented Approach. Agroecol. Sustain. Food Syst. 2013, 37, 3-18.

75. Klerkx, L.; Leeuwis, C. Shaping Collective Functions in Privatized Agricultural Knowledge and Information Systems: The Positioning and Embedding of a Network Broker in the Dutch Dairy Sector. J. Agric. Educ. Ext. 2009, 15, 81-105. [CrossRef]

76. Williams, P. The Competent Boundary Spanner. Public Adm. 2002, 80, 103-124. [CrossRef]

77. Koistinen, K.; Teerikangas, S.; Mikkilä, M.; Linnanen, L. Active Sustainability Actors: A Life Course Approach. Sustain. Dev. 2020, 28, 208-223. [CrossRef]

78. Brown, R.R.; Farrelly, M.A.; Loorbach, D.A. Actors Working the Institutions in Sustainability Transitions: The Case of Melbourne's Stormwater Management. Glob. Environ. Chang. 2013, 23, 701-718. [CrossRef] 